\title{
Performance of pre-stressed concrete sheet pile after long-term exposure in the marine splash environments
}

\author{
Rita Irmawaty ${ }^{1 *}$, Daisuke Yamamoto ${ }^{2}$, Hidenori Hamada ${ }^{2}$, and Yasutaka Sagawa ${ }^{2}$ \\ ${ }^{1}$ Hasanuddin University, Civil Engineering Department, 92171 Makassar City, , Indonesia \\ ${ }^{2}$ Kyushu University, Civil and Structural Eng. Dept., 744 Fukuoka City, Japan
}

\begin{abstract}
Pre-stressed concrete (PC) sheet piles are commonly used for river revetment, retaining wall, etc. However, it has not been used in port and harbor structure due to corrosive environmental conditions, which is severe for steel corrosion in concrete structure. Performances of PC sheet piles were evaluated after 12 years exposure in the marine splash environment. An evaluation of mechanical properties, carbonation depth, porosity, chloride content and PC steel condition were carried out. Overall, all specimens showed satisfactory performance: only a few concrete corner and edge chips, low chloride content and low rate of corrosion were observed. Investigation results indicated that BS5 $(B=$ GGBFS, $S=$ steam curing, and cover thickness of $5 \mathrm{~cm}$ ) showed the best performance (more durable), even though its strength was lower than the other.
\end{abstract}

\section{Introduction}

Pre-stressed concrete (PC) sheet piles are commonly used for river revetment, retaining wall, etc. However, it has not been used in port and harbor structure due to corrosive environmental conditions, which is severe for steel corrosion in concrete structure. Sheet pile rarely used in marine environment due to thin cover concrete, which is high possibility to corroded. Steel corrosion may occur directly through oxidation of metals or by penetration of aggressive substances through pores or cracks of the concrete cover [1], [2]. Such as reinforced concrete in general, deterioration due to reinforcement corrosion becomes the most important durability issue nowadays.

Chloride-induced corrosion is one of the main mechanisms of deterioration affecting the long-term performance of concrete structures. In Japan, a large majority of structures are built either near the costal or indirect contact with seawater. The durability of reinforced or pre-stressed concrete structure depends on the resistance of concrete to chloride penetration [3], [4]. Naturally concrete provides physical and chemical protection to the reinforcing steel from chloride penetrating. A chemical protection normally provided to all embedded steel due to the high-alkaline nature of Portland cement concrete. In addition, a physical protection is also provided by the concrete cover with adequate thickness. However, this

*Corresponding author: rita_irmawaty@yahoo.co.id 
protection is largely depending on the permeability of the concrete and the cover thickness of steel bars [5], [6].

Concrete strength over $50 \mathrm{MPa}$ seems to be one solution to achieve low permeability and high durability for long-term exposure in marine environment. In addition, partial replacement of cement by Blast Furnace Slag (BFS) in producing High Strength Concrete (HSC) has been established. The objective of this study is to obtain experimental data to discuss an adequate cover thickness of PC sheet pile under marine conditions and effectiveness of BFS to enhance chloride resistance. In this study, PC sheet pile model specimens were exposed under marine splash environment during 12 years.

\section{The material and method}

\subsection{Materials}

The specimens were made with High Early Strength of Portland Cement (HSPC), Ground Granulated Blast Furnace Slag (GGBFS), river sand, crushed stone, with additional $\mathrm{HRWR}+\mathrm{AE}$ admixture to improve the performance of concrete. Material properties used in this study are described in Table I and II.

Tabel 1. Physical and Chemical Compositions of Cements [7]

\begin{tabular}{|l|l|l|}
\hline Items & HSPC & GGBSF \\
\hline Density, $\mathrm{g} / \mathrm{cm}^{3}$ & 3.14 & 2.92 \\
\hline Blaine fineness, $\mathrm{cm}^{2} / \mathrm{g}$ & 4550 & 6020 \\
\hline $\mathrm{MgO} \%$ & 1.4 & 6.2 \\
\hline $\mathrm{SO}_{3}, \%$ & 2.9 & 0.1 \\
\hline $\mathrm{LOI} \%$ & 1.3 & 0.2 \\
\hline Total alkali, \% & 0.56 & - \\
\hline Ion chloride, \% & 0.004 & 0.005 \\
\hline
\end{tabular}

Tabel 2. Properties of Materials [7]

\begin{tabular}{|l|l|}
\hline Material & Specification \\
\hline Fine aggregate & River sand \\
& Density $=2.62 \mathrm{~g} / \mathrm{cm}^{3}$ \\
\hline Coarse aggregate & Crushed stone \\
& Density $=2.62 \mathrm{~g} / \mathrm{cm}^{3}, \mathrm{MSA}=20 \mathrm{~mm}$ \\
\hline HRWR+AE admixture & Polycarboxylate ether based \\
\hline AE admixture & Alkylcarboxylic based \\
\hline
\end{tabular}

\subsection{Mix Proportions}

The mixture proportions of concrete are summarized in Table III. The water to binder ratio $(\mathrm{w} / \mathrm{b})$ was $32 \%$ with target slump and air content about $8.0 \pm 2.5 \mathrm{~cm}$ and $4.0 \pm 1.0 \%$, respectively. Both air-entraining admixture; and air-entraining and water-reducing admixture were used based on the cement mass. Compressive strength design was $70 \mathrm{MPa}$. 
Tabel 3. Mix Proportion [7]

\begin{tabular}{|l|l|l|}
\hline Material & Mix-1 & Mix-2 \\
\hline Sand-aggregate ratio s/a, \% & 45.3 & 44.9 \\
\hline Water, $\mathrm{kg} / \mathrm{m}^{3}$ & 150 & 150 \\
\hline Cement, $\mathrm{kg} / \mathrm{m}^{3}$ & 469 & 234 \\
\hline GGBFS, $\mathrm{kg} / \mathrm{m}^{3}$ & - & 234 \\
\hline Fine aggregate, $\mathrm{kg} / \mathrm{m}^{3}$ & 784 & 770 \\
\hline Coarse aggregate, $\mathrm{kg} / \mathrm{m}^{3}$ & 950 & 949 \\
\hline
\end{tabular}

\subsection{Specimen Design}

There are four sheet pile specimens, name as "PN3", "BS5", "PN5" and "PS7". The name index is indicated by [P for HSPC, B for GGBFS, $\mathrm{N}$ for water curing, $\mathrm{S}$ for steam curing and the number $(3,5$ and 7 ) indicate cover depth in $\mathrm{cm}]$. Details of mix and curing condition of specimens are described in Table IV.

Tabel 4. Mix and Curing Condition of Sheet Pile Model

\begin{tabular}{|l|l|l|c|}
\hline Specimen & Mix condition & Curing Condition & $\begin{array}{c}\text { Thickness } \\
\text { (cm) }\end{array}$ \\
\hline PN3 & Mix-1 & Condition-2 & 7 \\
\hline BS5 & Mix-2 & Condition-1 & 11 \\
\hline PN5 & Mix-1 & Condition-2 & 11 \\
\hline PS7 & Mix-1 & Condition-1 & 15 \\
\hline
\end{tabular}

Note:

- $\quad$ Curing condition-1: 1 day steam, followed by 2 days wet, then covering by vinyl sheet.

- Curing condition-2: 3 days wet, then covering by vinyl sheet.

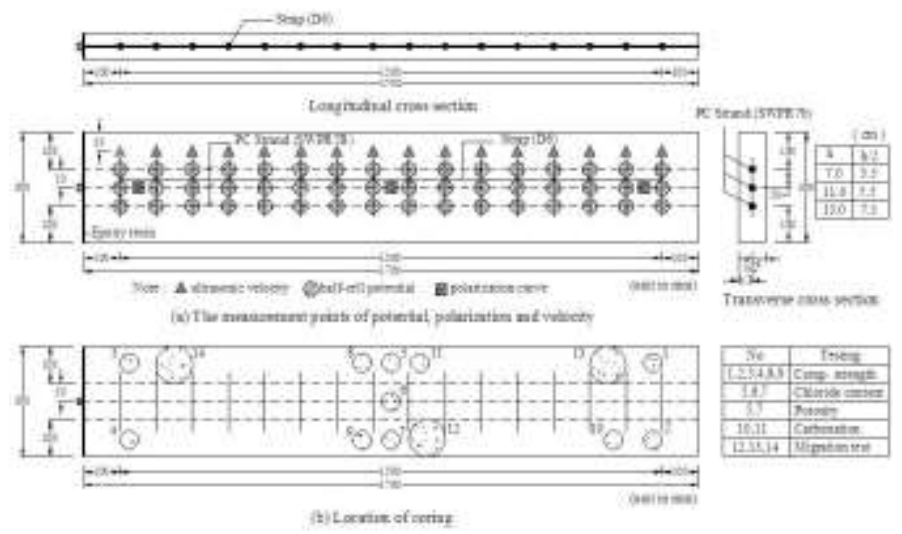

Fig. 1 Sheet pile specimen model geometry and measurement point

Figure 1 shows sheet pile specimen model geometry and measurement points of halfcell potential, polarization curve, ultrasonic pulse velocity and core sampling. As shown in this figure, PC sheet pile dimension in $1,700 \mathrm{~mm} \times 300 \mathrm{~mm}$, and height varies from 70, 110 and $150 \mathrm{~mm}$ with cover thickness is 30,50 and $70 \mathrm{~mm}$, respectively. The variation in 
thickness aims to evaluate the effect of cover depth as natural protection on concrete to chloride ion penetration. In center line of specimen, three PC strands (SWPR7B) with distance of $100 \mathrm{~mm}$ from the edges were embedded. In order to fix the position of strands, 16 straps were placed with spacing of $100 \mathrm{~mm}$.

\subsection{Curing Condition and Exposure Test}

The main difference lies in curing, that is after casting steam curing or water curing for a day, followed by vinyl sheet covering for 2 months (see Table 4). Then accelerated deterioration test was conducted in the laboratory, as repeated wet-dry cycle. One cycle was 3.5 days, consisted of 1 day wet (sprayed warm seawater of $40^{\circ} \mathrm{C}$ ) and 2.5 days air dry, continued until 220 cycles ( 770 days all). The number of 220 cycles is estimated to be equal to 3 years in the real-time exposure study [4].

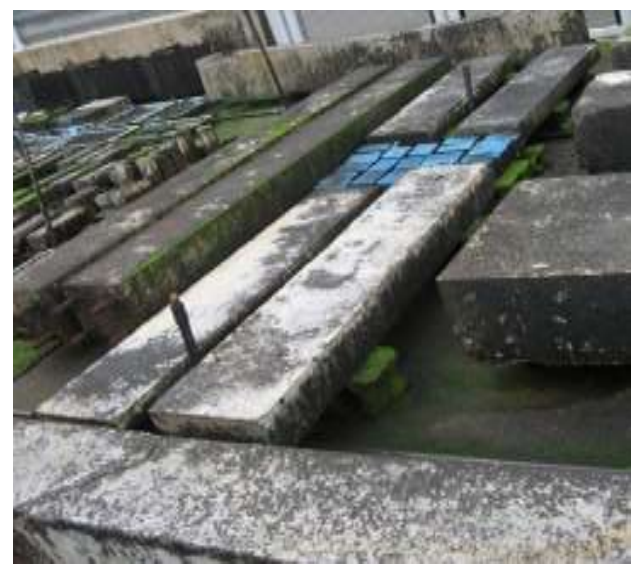

Fig. 2 Sheet pile specimen

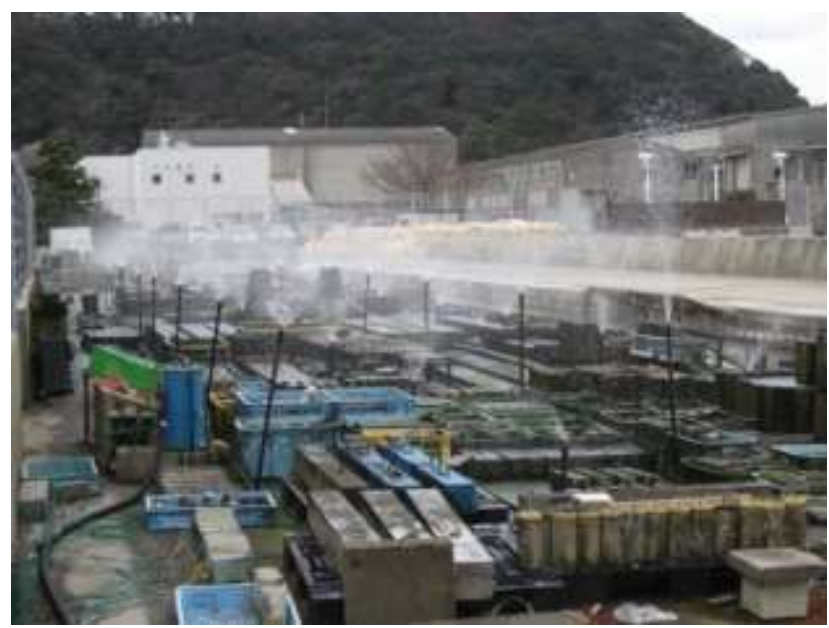

Fig. 3 Seawater splashing condition 
Furthermore, specimens were placed in an open space and exposed to seawater splashing. The specimens were subjected to 2 cycles of wetting and drying a day. One cycle was seawater splashing for 4 hours and drying for 8 hours; during 12 years. Figure 2 and 3 show sheet pile specimens in the exposure site and condition when seawater is splashing.

\subsection{Method of Evaluation}

After 220 cycles of accelerated test, several tests were conducted. Details of testing and the results have been published [7]-[9]. Furthermore, in this paper we will present condition after 12 years of continuous exposure under marine splash environments. First, specimens were transferred from the exposure site to the laboratory and cleaned. Then specimens were investigated for corrosion of steel bar by using half-cell potential and anodic polarization curve by contact method. The half-cell potential was measured at interval $100 \mathrm{~mm}$ for each strand; whereas polarization curve was only checked at three points $(15 \mathrm{~cm}$ from both edges and in the middle of specimen). The measurement was conducted with the silver/silver chloride electrode after 1 hour of pre-wetting.

In addition, ultrasonic pulse velocity (UPV) was measured by the direct method with path length of $100 \mathrm{~mm}$. The UPV reading was conducted at 16 points along sheet pile. After that, core samples of $50 \mathrm{~mm}$ in diameter, were taken for compressive strength, chloride analysis, porosity and carbonation depth testing. Compressive strength was measured according to JIS A 1108. Testing was conducted on six core samples for each specimen. At the same time, a static elastic modulus was also conducted.

Chloride ion concentration was measured at certain depths of core samples $(50 \mathrm{~mm}$ in diameter) based on JCI-SC4. Cores were taken from three points at midspan of the sheet pile. Then cores were cut into 5 pieces (thickness varied from 10 to $20 \mathrm{~mm}$ ) and crushed into powder. Porosity of the mortar samples was measured at depth of 30 to $40 \mathrm{~mm}$ of core samples. Then pore size distribution of the samples was evaluated by MIP (Mercury Intrusion Porosimetry). Carbonation depth was evaluated on freshly cut surface of core samples after spraying a $1 \%$ phenolphthalein solution.

Effective chloride diffusion was evaluated by electric migration technique according to JSCE-G571-2003, where core samples (100 mm in diameter) were taken, and cut $30 \mathrm{~mm}$ from the surface of the sample. Then concrete sample divides the anode $(0.5 \mathrm{~mol} / \mathrm{L}$ of $\mathrm{NaCl}$ solution) and cathode $(0.3 \mathrm{~mol} / \mathrm{L}$ of $\mathrm{NaOH}$ solution $)$ of a migration cell. The constant $\mathrm{DC}$ potential of 9 Volts was applied across the cell, and negatively charged chloride ions migrate from the cathode toward the anode through the concrete pore solution.

\section{Results and discussion}

\subsection{Visual observation}

Observations were made by washing the exterior surface of the specimens, then carried out checks on all corner, edge and surface of the specimen whether the steel corrosion has occurred. If steel corrode, there are usually signs of deterioration on the concrete surface such as rusting, cracking and spalling. From visual inspection, there were no adequate information on the corrosion risk of steel embedded in concrete, and only a few concrete corner and edge chips were observed. This was caused by the removal of surface mortar and fine aggregate as a result of seawater splashes. Degradation phenomenon such as small cracks or leaching of rebar rust is not identified. 


\subsection{Mechanical Properties}

Compressive strength of concrete specimens after 12 years exposure in the marine splash environment is shown in Figure 4. The value is based on average of 6 core samples for each specimen. It is found that strength of concrete decreased slightly. Decrement in strength was observed in all specimens with maximum $4.7 \%$ reduction (in case of PN5). There is no significant difference in strength decreasing between steam and water curing.

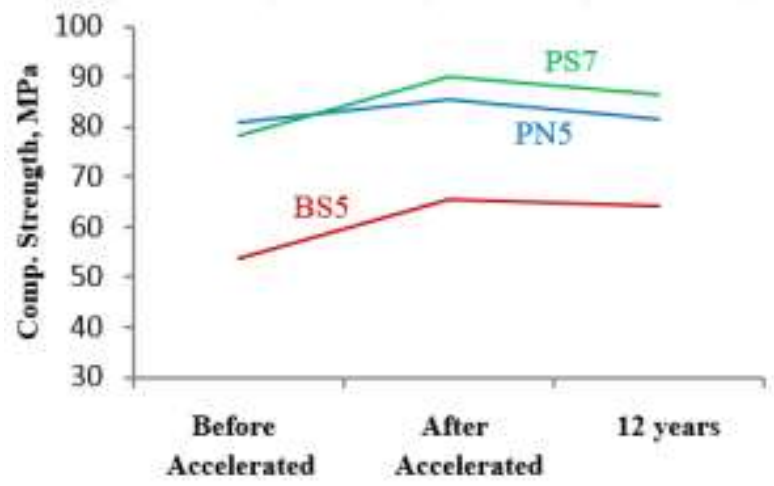

Fig. 4 Compressive strength of concrete

The pulse velocity varies between 4.50 and $4.63 \mathrm{~km} / \mathrm{s}$ with coefficient of variation of 0.81 to $1.44 \%$ as shown in Figure 5. A good correlation between compressive strength and pulse velocity value is found, where the higher of strength, the higher value of pulse velocity are observed. On the contrary, from Figure 6, it is found that the elastic modulus of concrete increased (maximum 11\%) after 12 years exposure, and no significant variation between compressive strength and elastic modulus data was observed. It confirms that the degradation of concrete properties in macroscale is not significantly occured.

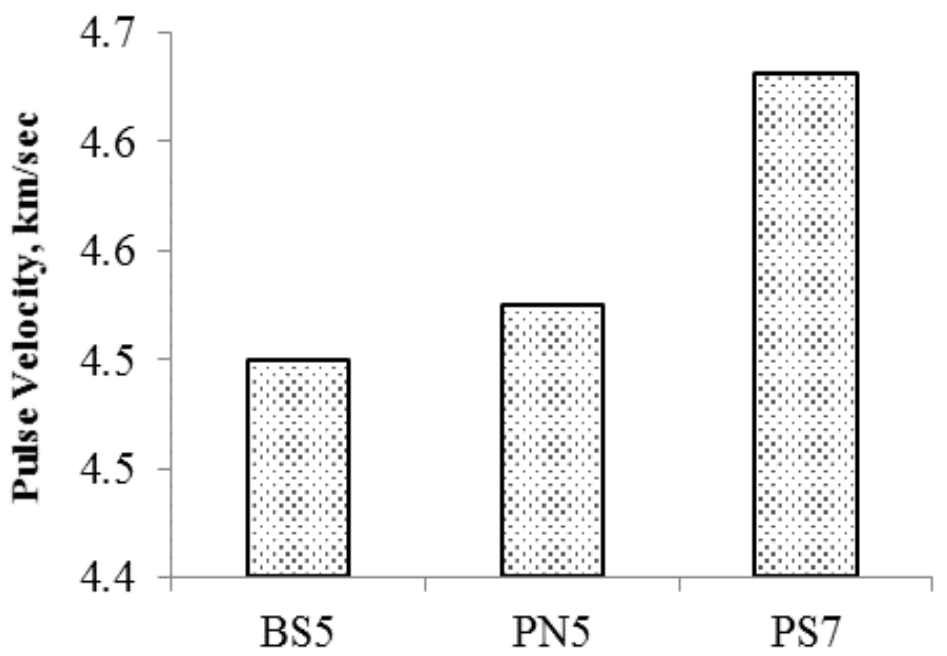

Fig. 5 Pulse Velocity after 12 years exposure 


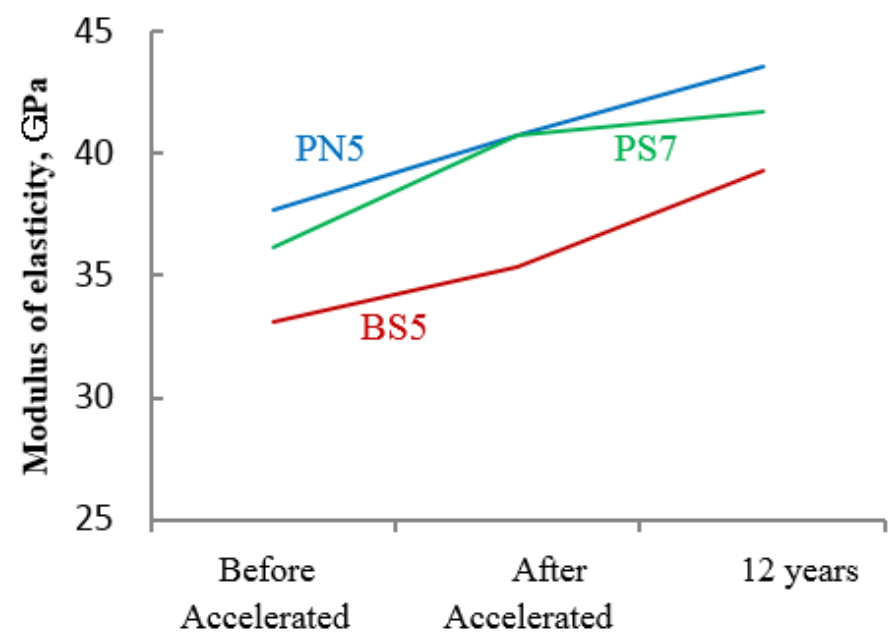

Fig. 6 Elastic modulus of concrete

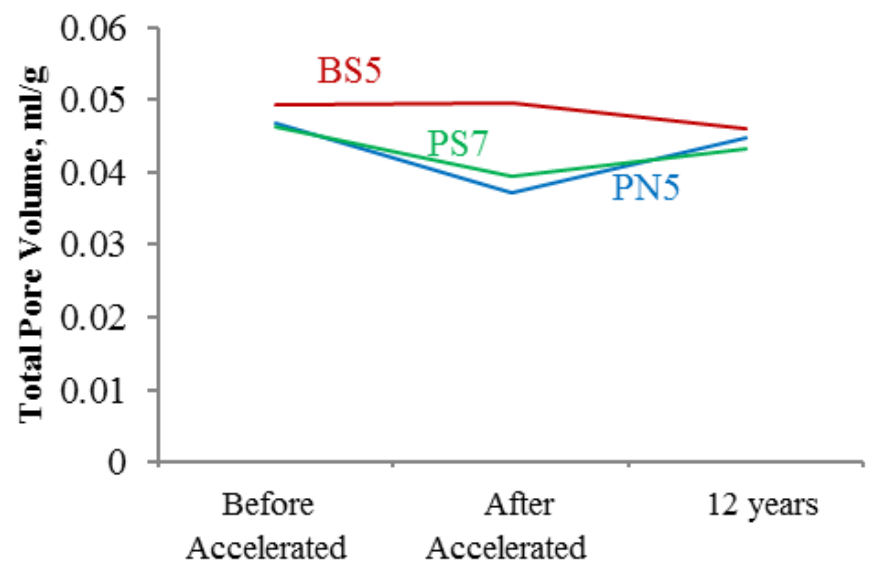

Fig. 7 Pore volume

\subsection{Porosity and Depth of Carbonation}

Pore volume and pore size distributions of the mortar samples collected at 30-40 mm depth of the specimens are shown in Figure 7 and Figure 8 where porosity and pore size distribution in a certain range show almost the same trend for all specimens. It is found that porosity of PN5 and PS7 increase after 12 years exposed to a corrosive environment, and vice versa in BS5 as shown in Figure 7. It seems that partial replacement of cement by GGBFS causes a reduction in the pore volume, and may also cause a reduction in the connectivity of the capillary pore. The capillary pore defined here is the porosity of pores whose diameter ranging from 0.01 to $5 \mu \mathrm{m}$ [10]. In addition, the capillary pore distribution was slightly higher for BS5 than the other, but it did not affect significantly. 


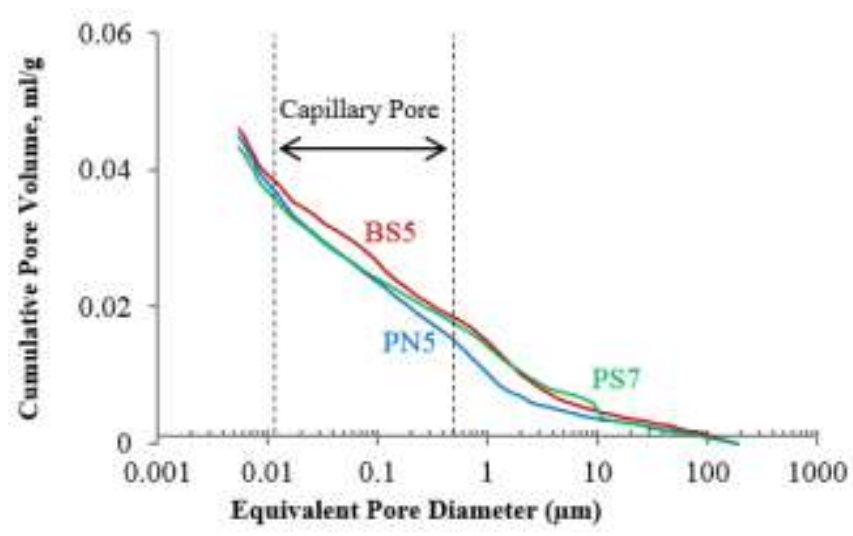

Fig. 8 Porosity of mortar samples

Carbonation depths of the core samples were not identified in this investigation. This is caused by the compactness of concrete where the total pore volume was very small (about $10 \%)$.

\subsection{Chloride Content in Concrete}

Total amount of chloride ion as a percentage of cement mass at 30,50 and $70 \mathrm{~mm}$ depth from the surface of specimen is shown in Figure 9. The amount of chloride content varied between $0.134 \%$ and $0.365 \%$ at the depth of $30 \mathrm{~mm}$, whereas at $50 \mathrm{~mm}$ depth showed a little amount which varies between $0.069 \%$ and $0.118 \%$. It is found that sheet pile composed of GGBFS shows the lowest amount of chloride content compared with others at the same depth. It indicates that the microstructure of concrete using GGBFS is significantly improved and can provide a good barrier against chloride-inducement.

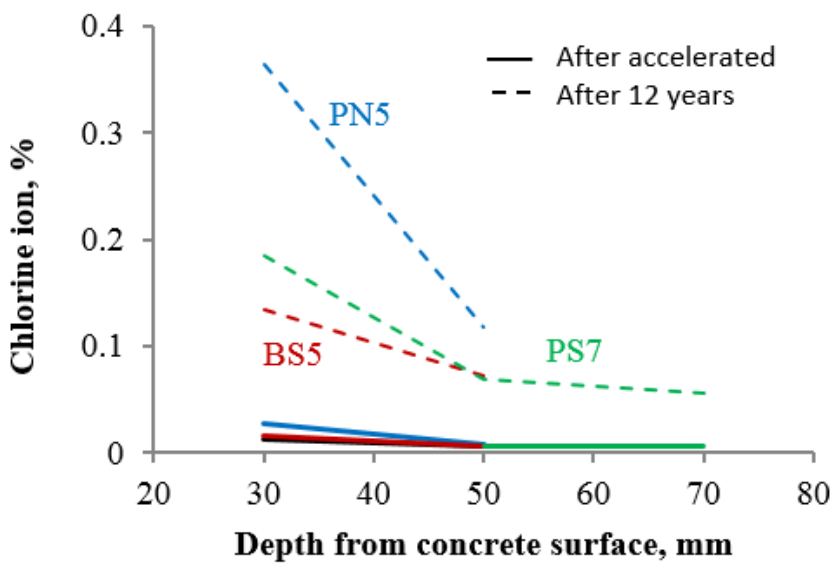

Fig. 9 Average of chloride ion in concrete 
Numerous studies have shown that when present in sufficient quantities, chloride ions will promote the corrosion of steel in concrete [1], [2]. If the chloride content of $0.4 \%$ (by mass of cement) in the concrete is assumed as a threshold value for the initiate of steel corrosion, nowadays position of $0.4 \%$ chloride content in specimens of BS5, PN5, and PS7 are in the depths of $1.12 \mathrm{~cm}, 2.7 \mathrm{~cm}$ and $2.02 \mathrm{~cm}$ respectively from the surface.

\subsection{Chloride diffusion coefficient}

The diffusion coefficient (D) and concrete cover combine to provide a measure of the resistance of concrete to chloride ingress. Both the apparent (Da) and effective (De) diffusion coefficient were measured, and the results could be seen in Table V. The apparent diffusion coefficient (Da) was measured from non-steady-state of chloride test using Fick`s second law, while De was measured from steady-state of chloride test using Fick`s first law.

Tabel 5. Diffusion Coefficient (D) of Specimens

\begin{tabular}{|l|l|l|}
\hline Name & $\begin{array}{l}\text { Da } \\
\left(\mathrm{cm}^{2} / \text { year }\right)\end{array}$ & $\begin{array}{l}\text { De } \\
\left(\mathrm{cm}^{2} / \text { year }\right)\end{array}$ \\
\hline BS5 & 0.1435 & 0.120 \\
\hline PN5 & 0.2294 & 0.379 \\
\hline PS7 & 0.2136 & 0.399 \\
\hline
\end{tabular}

From the Table V, BS5 showed the lowest diffusion coefficient. It means BS5 has good resistance to chloride ingress as compared to the other.

\section{A. PC Strand Monitor}

Natural Electrode Potential Test: Figure 10 shows the natural electrode potential after 12 years exposure in the marine splash environment. Significant change in natural electrode potential of strands occurred in PN3 and showed increasing potential for corrosion. On the other hand, irrespective of cement type, PC sheet pile height of 11 and $15 \mathrm{~cm}$ have potential value in the range of -56 to $-101 \mathrm{mV}: \mathrm{CSE} / 25^{\circ} \mathrm{C}$. According to ASTM C876-91 (1999), potential less negative than $-200 \mathrm{mV}$ :CSE indicates $90 \%$ probability of no corrosion.

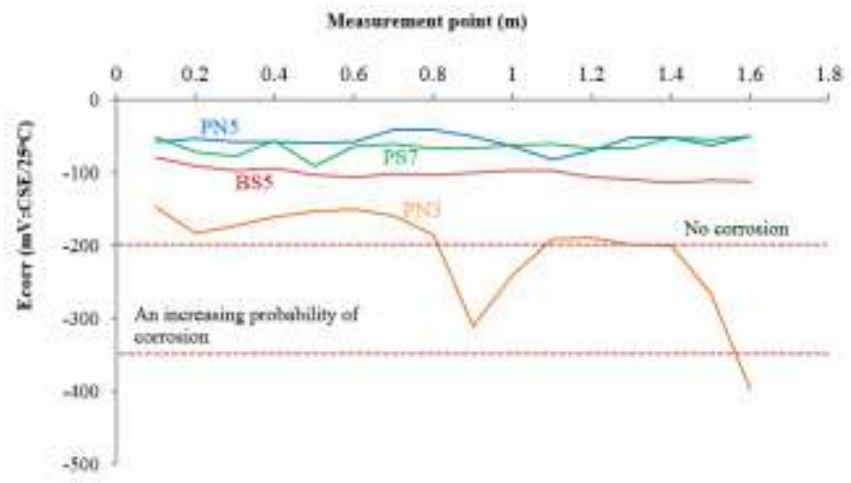

Fig. 10 Natural electrode potential

As comparison, PN3 with thickness of $7 \mathrm{~cm}$ is used. From the Figure 10, it can be seen that the potential value decreased sharply in some points. Then potential value in the range of 150 to $-400 \mathrm{mV}: \mathrm{CSE} / 25^{\circ} \mathrm{C}$, indicates an increasing probability of corrosion. This is caused 
by the presence of small cracks in some parts of sheet pile as a result of the strand corrosion development on the edge whose no cover concrete. It can be concluded that PC sheet pile with thickness of $7 \mathrm{~cm}$ only has a 20 -year service life, and it is recommended to increase the thickness to $11 \mathrm{~cm}$ to improve the durability.

Tabel 6. Average Polarization Resistance of Steel [2]

\begin{tabular}{|c|c|c|c|}
\hline $\begin{array}{c}\text { Speci } \\
\text { men }\end{array}$ & $\begin{array}{l}\text { Polariza } \\
\text { tion } \\
\text { Resistance } \\
\left(\mathrm{k} \Omega . \mathrm{cm}^{2}\right)\end{array}$ & $\begin{array}{l}\text { Corrosio } \\
\text { Penetration } \\
(\mu \mathrm{m} / \text { year })\end{array}$ & $\begin{array}{c}\text { Rate of } \\
\text { Corrosion }\end{array}$ \\
\hline PN3 & 245 & $\begin{array}{l}1.46 \\
0.539\end{array}$ & $\begin{array}{l}\text { Low/mode } \\
\text { Passive }\end{array}$ \\
\hline BS5 & 564 & 1.34 & $\begin{array}{c}\text { Low/mode } \\
\text { rate }\end{array}$ \\
\hline PS7 & 228 & 1.6 & $\begin{array}{c}\text { Low/mode } \\
\text { rate }\end{array}$ \\
\hline
\end{tabular}

From the view point of polarization resistance of steel (Rct) as described in Table VI, BS5 showed passive corrosion rate with value larger than $250 \mathrm{k} \Omega . \mathrm{cm}^{2}$, whereas PN3, PN5 and PS7 showed a low/moderate corrosion rate. It indicates that BS5 (50\% partial replacement of cement by GGBFS) provided higher resistance to chloride ingress than the other.

Polarization Curve: Anodic polarization curve of each specimen is shown in Figure 11. PC strands were embedded in concrete exhibited various polarization curve with potential between 0.2 and $0.6 \mathrm{~V}$, and current density were the range between 1 to $10 \mu \mathrm{A} / \mathrm{cm}^{2}$, and 10 to $100 \mu \mathrm{A} / \mathrm{cm}^{2}$. Based on the passivation film associated with anodic polarization curve, $\mathrm{BS} 5<\mathrm{PS} 7<\mathrm{PN} 5$ can be classified into grade 3 and PN3 is grade 1 as a degree of passivity exist [2].

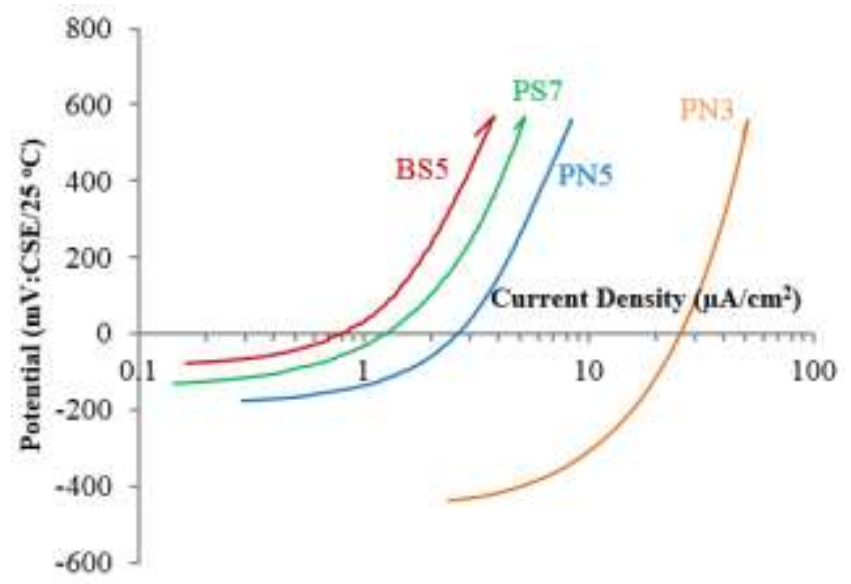

Fig. 11 Anodic polarization curve

Average of corrosion potential is sequenced as $\mathrm{BS} 5<\mathrm{PS} 7<\mathrm{PN} 5<\mathrm{PN} 3$ with values ranging from -125 to $-370 \mathrm{mV}$ :CSE. Irrespective of the cement types and curing conditions at the early life of concrete, for the same cover thickness, PN5 exhibited more potential corrosion compared to BS5. It shows that GGBFS is a good barrier against chloride-induced due to compactness of microstructure, hence it can reduce the risk of corrosion. In addition, results 
from both anodic polarization curve and natural electrode potential test showed that PN3 has started to corrode after 12 years exposure.

Verification of Rebar Corrosion: From Figure 12, it can be seen that there was a little corrosion on the ends of strand caused by the absence of cover concrete and was characterized by the presence of leaching of rebar rust in the concrete. However, this little corrosion did not affect the whole strand. While in PN3 as shown in Figure 12 (c), on the edge of strand whose no cover, strand was corroded along the 5 to $7 \mathrm{~cm}$ and the ends of strand have been ruined. Total area of corrosion was observed after removing all concrete is approximately $1.01 \%$.

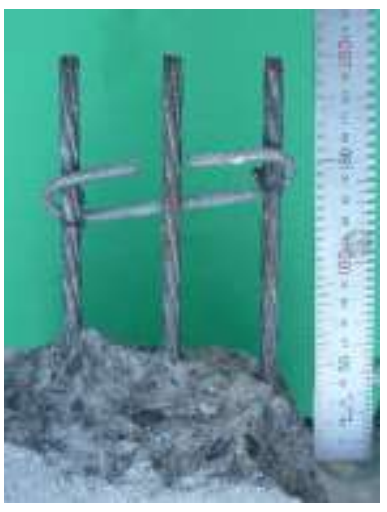

(a)

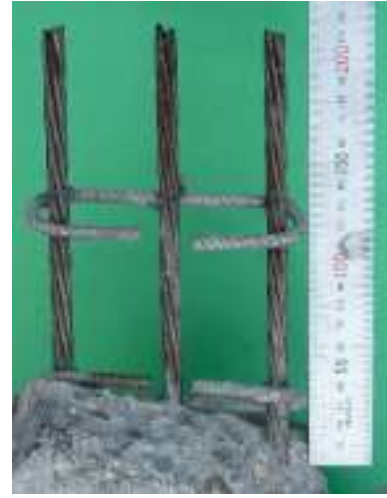

(b)

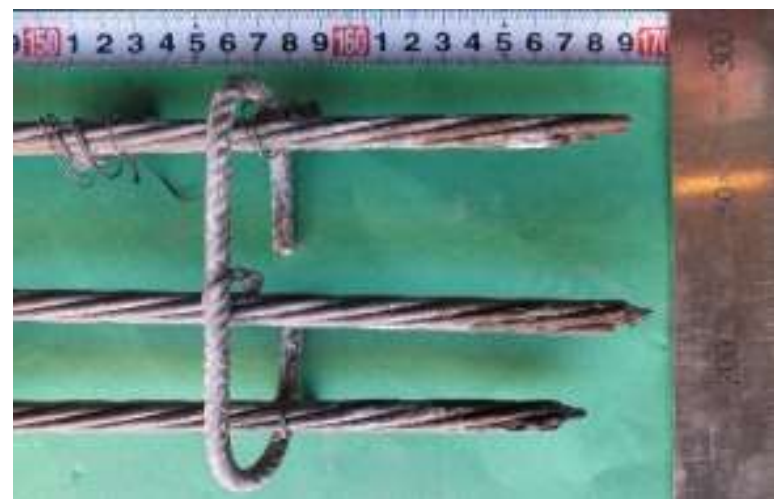

(c)

Fig. 22 Verification of rebar corrosion by removing cover concrete

(a) BS5; (b) PN5; (c) PN3

\section{Conclusion}

In order to evaluate the performance of PC sheet pile under marine splash environment, repeated of wet-dry cycle were conducted. The results obtained may be summarized as follows:

1. Compressive strength decreased slightly after prolonged exposure in the marine splash environment while the elastic modulus kept increasing.

2. The pore volume increased both in PN5 and PS7, but decreased in BS5. Meanwhile, pore size distribution showed a similar trend in the range of capillary pore. 
3. Carbonation were not identified in this investigation.

4. Chloride content in specimens is less than $0.4 \%$ by mass of cement which indicates that corrosion has not yet occurred.

5. All PC strand embedded in concrete exhibited good passivity and only a little corrosion on the ends of strand caused by the absence of cover concrete, except PN3 that showed increasing potential for corrosion. It is recommended to increase the thickness of PC sheet pile become $11 \mathrm{~cm}$ to improve the durability.

6. Specimen BS5 showed the best performance, which can provide a good barrier against chloride-induced due to compactness of microstructure and can reduce the risk of corrosion.

\section{NOMENCLATURE}

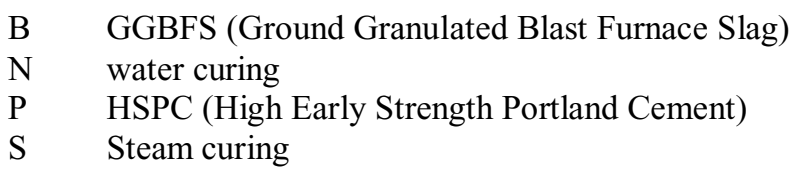

\section{ACKNOWLEDGMENT}

We would like to thank The Port and Airport Research Institute Japan, who has prepared the specimen.

\section{References}

1. T. Amino, N. Otsuki, et al, "The influence of Chloride Content at the Rebar on Corrosion Progress in Concrete of Dolphins", in Proc. $34^{\text {th }}$ Conference on Our World in Concrete \& Structures, Singapore, (2009).

2. N. Otsuki, "A study of Effectiveness of Chloride on Corrosion of Steel Bar in Concrete", Report of Port and Harbor Research Institute:127-134, (2003).

3. Seung Lee, Subbiah Karthick, et.al, "Long-term corrosion performance of blended cement concrete in the marine environment - A real-time study", Construction and Building Materials, Vol. 154, pp. 349-360, Nov. (2017).

4. M. Robert, et al, "Durability of Precast Prestressed Concrete Piles in Marine Environment: Reinforcement Corrosion and Mitigation-Part 1", Final Report, pp. 2-32, June (2011).

5. M. Santhanam, M. Otieno, "5-Deterioration of concrete in the marine environment", Marine Concrete Structures, Design, Durability and Performance, pp 137-149, (2016).

6. P.C. Aitcin, "The durability characteristics of High Performance Concrete: a review", Cement \& Concrete Composites, No. 25, pp. 409-420, (2003).

7. H. Hamada, H. Yokota, Y. Kikuchi, "Durability Evaluation of Pre-stressed Concrete Sheet Pile under Marine Corrosive Environments by Acceleration Test", Technical Note of The Port and Airport Research Institute, No. 1097, June 2005 (in Japanese). (2005).

8. H. Hamada, K. Nakahashi, R. Kuroki, "An Acceleration Test for Chloride Ion Permeability and Corrosion of Steel Embedded of High Strength Concrete”, Annual Papers of JCI, Vol. 21, No. 2, pp. 979-984, (1999) (in Japanese).

9. N. Yuasa, H. Hamada, Y. Miyazaki, "An Acceleration Test of PC Sheet Pile for Durability Evaluation Under Marine Environment", Annual Papers of JCI, Vol. 21, No. 2, (1999), pp. 1027-1032 (in Japanese). 
10. Lu Cui, J.H. Cahyadi, "Permeability and pore structure of OPC paste", Cement and Concrete Research, Vol. 31, pp. 277-282, 2001.

11. P. K.. Mehta and PJM. Monteiro, Concrete: Microstructure, Properties, and Materials, $3^{\text {rd }}$ ed", Mc Graw Hill, pp. 442, 2006.

12. H. Hamada, Y. Sagawa, T. Ikeda, R. Morikawa, "Several Factors Affecting the Anodic Polarization Curve of Steel Bars Embedded in Mortar", in Proc. $6^{\text {th }}$ International Conference on Concrete Under Severe Conditions, Environment and Loading, Mexico, (2010). 